\title{
O INTELECTUAL DA MARGEM E O PODER VERSUS A RESISTÊNCIA E O REVIDE DAS VOZES PERIFÉRICAS EM CAIEIRA
}

\author{
Carmelita Rodrigues Gomes ${ }^{1}$ \\ Universidade Federal da Grande Dourados \\ (carmelitarg2000@yahoo.com.ar) \\ Rogério Silva Pereira ${ }^{2}$ \\ Universidade Federal da Grande Dourados \\ (rogeriospereira@uol.com.br)
}

\begin{abstract}
Resumo: O presente artigo pretende mostrar, dentro do romance Caieira (1978), o papel do escritor latino-americano mato-grossense Ricardo Guilherme Dicke ${ }^{3}$ como um intelectual da margem. Daremos destaque para o fato de que seus personagens marginais são caracterizados pela não integração na sociedade devido à imposição opressiva mimetizada pelo norte-americano, Mr. Filler, personagem antagonista. Em atitude típica do intelectual engajado que, não só interpreta a realidade, mas também se põe a transformá-la, o escritor configura na narrativa uma situação de revide que funciona como ferramenta para materializar seus ideais políticos, sociológicos e literários. Assim sendo, num entrecho emblemático ficcional, a superioridade do norte-americano e tudo que ele representa é desconstruído. Em contrapartida, os sem vozes são emancipados conquistando seu espaço como sujeito. No desenrolar do estudo serão levadas em consideração as opiniões teóricas de pensadores, como BHABHA (1998); SAID (2005); SARTRE (1994); CHAUÍ, (2006) e outros, dentre outros. Simultaneamente, pretende-se fazer uma breve análise de algumas das partes da obra citada. Desse modo, alguns conceitos serão ilustrados através da trajetória de alguns personagens, mais especificamente, Mr. Filler, Nheco Salmo, nhá Emerica, Amância e Pignon.
\end{abstract}

Palavras-chave: Dicke; Intelectual; Margem; Poder; Revide.

Abstract: The present article intends to show, within the romence Caieira (1978), the role of the Latin American writer mato-grossense Ricardo Guilherme Dicke as an intellectual on the sidelines. We will highlight the fact that its marginal characters are characterized by non-integration into society due to the oppressive imposition mimicked by the American, Mr. Filler, antagonistic character. In a typical attitude of the engaged intellectual who not only interprets reality but also sets out to transform it, the

\footnotetext{
${ }^{1}$ Mestranda em Letras (Literatura e Práticas Culturais) da Universidade Federal da Grande DouradosMS. Dourados - MS - Brasil.

2 Professor na UFGD - Universidade Federal da Grande Dourados. FACALE - Faculdade de Comunicação Artes e Letras. Dourados - MS - Brasil.

${ }^{3}$ Nasceu em 16 de outubro de 1936, em Raizama, no município de Chapada dos Guimarães, MT. Faleceu no dia 9 de julho de 2008. É autor de uma produção literária que tem o romance como gênero predominante, embora também tenha escrito poesia, conto e teatro. Sua estreia literária oficial ocorreu em 1968, com a publicação do romance Deus de Caim, 4ํ lugar no Prêmio Walmap, que teve no júri Jorge Amado, Guimarães Rosa e Antônio Olinto. Data do mesmo ano a publicação de seu segundo romance, Como o silêncio, com o qual conquistou o segundo lugar no Prêmio Clube do Livro de São Paulo.

A produção literária do escritor seguiu com a publicação do romance Caieira (1978), Prêmio Remington de Prosa, em 1977; Madona dos Páramos (1982), Prêmio Nacional da Fundação Cultural do Distrito Federal em (1981); O último Horizonte (1988); A Chave do Abismo (1989), coletânea de poemas; Cerimônia do esquecimento (1995), Prêmio da Academia Brasileira de Letras; Conjuntia Opositorum do Grande Sertão - tese de mestrado em Filosofia sobre Grande Sertão: Veredas (2000); Rio Abaixo dos Vaqueiros (2000); Salário dos Poetas (2001); Toada do esquecido \& Sinfonia Equestre (2006).
} 


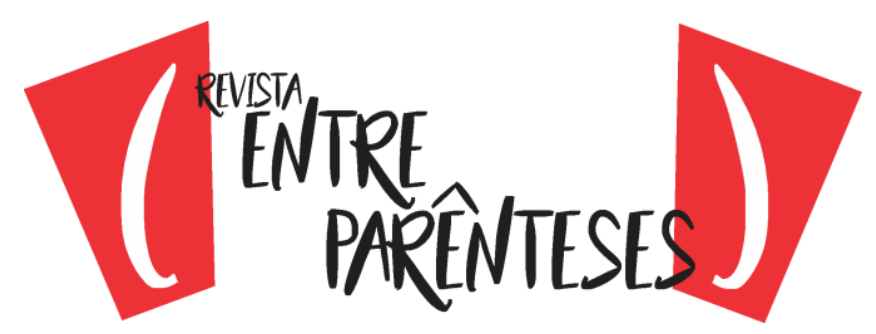

writer configures in the narrative a situation of revolver that functions as a tool to materialize his political, sociological and literary ideals. Like this, in an emblematic fictional hag, the superiority of the American and all that he represents is deconstructed. In contrast, the voiceless are emancipated conquering their space as subject. In the course of the study will be taken into consideration the theoretical opinions of thinkers such as BHABHA (1998); SAID (2005); SARTRE (1994); CHAUí, (2006) e outros, among others. At the same time, it is intended to make a brief analysis of some of the parts of the work cited. In this way, some concepts will be illustrated through the trajectory of some characters, more specifically Mr. Filler, Nheco Salmo, nhá Emerica, Amância and Pignon

Keywords: Dicke; Intellectual; Edge; Power; Revide

Resumen: El presente artículo pretende mostrar, dentro de la novela Caieira (1978), el papel del escritor latinoamericano mato grosense Ricardo Guilherme Dicke como un intelectual de la margen. Se destacará el hecho de que sus personajes marginales se caracterizan por no estar integrados a la sociedad debido a la imposición opresiva mimetizada por el norteamericano, Mr. Filler, personaje antagonista. En una actitud típica del intelectual comprometido que, no sólo interpreta la realidad, sino que también se pone a transformarla, el escritor configura en la narrativa una situación de antagonismo que actúa como herramienta para materializar sus ideales políticos, sociológicos y literarios. Así, en un enredo emblemático ficcional, la superioridad del norteamericano y todo lo que representa es colocado es desconstruído. En cambio, los sin voces son emancipados conquistando su espacio como sujeto. En el desarrollo del estudio se tendrán en cuenta las opiniones teóricas de pensadores, como BHABHA (1998); SAID (2005); SARTRE (1994); CHAUÍ, (2006), entre otros. Simultáneamente, se pretende hacer un breve análisis de algunas de las partes de la obra citada. De este modo, algunos conceptos serán ilustrados a través de la trayectoria de algunos personajes, más específicamente, Mr. Filler, Nheco Salmo, nhá Emerica, Amancia y Pignon.

Palabras-clave: Dicke; Intelectual; Margen; Poder, Antagonismo.

É sangue sempre sangue, sangue de todos os lados... A gente respira sangue, vira sangue, se rebola no sangue, vive no sangue, tudo sangue... (DICKE, 1978, p.32).

(...) comigo estes vagabundos têm que trabalhar e não sou de muita conversa. Sou o segundo aqui depois do americano (DICKE, 1978, p. 270)

Os trechos acima, retirados da obra Caieira (1978), do escritor matogrossense Ricardo Guilherme Dicke, são apenas uns dos muitos referenciais configurados, em sua obra, que nos auxiliam a caracterizá-lo como um intelectual da margem. No primeiro trecho, está a denúncia pelo paroxismo da violência - "sangue, sangue"; no segundo, fala um personagem opressor, assumindo-se como tal.

Ser da margem significa ser do "contra", escrever não de acordo com o status quo, mas contestando-o. Nesse aspecto, o posicionamento ideológico, político do escritor em questão, revelado em suas narrativas, combina com as reflexões sobre a função do intelectual defendidas pelo pensador palestino contemporâneo Edward Said. Para ele, o intelectual deve praticar um discurso descentralizado, deve 


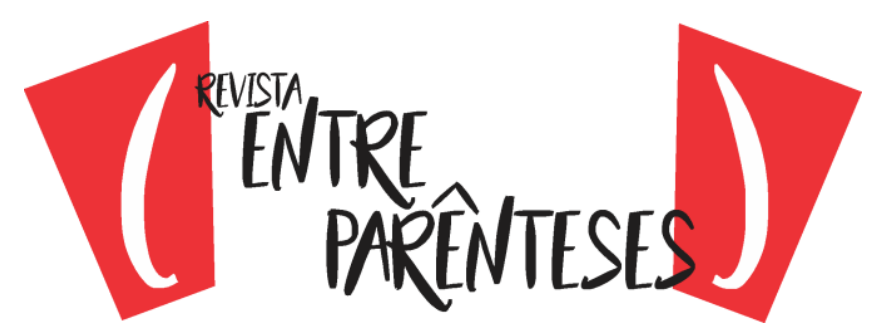

falar a partir da margem, por isso sua condição é do exílio, a do "fora-do-lugar". Deve ser alguém que se "(...) recusa a aceitar fórmulas fáceis ou clichês prontos, ou confirmações afáveis" (SAID, 2005 p. 35), evitando, dessa forma, que sua produção esteja enjaulada no agrado às convenções eurocêntricas.

Corroborando com tal pensamento, a posição enunciativa presente em Caieira é complexa e problemática. Fato que contribui para transgredir a ideologia dominante que prevaleceu na literatura até meados do século XIX. Nesse período, o intelectual "oitocentista brasileiro se contentava em estar em dia, na medida do possível, com as novidades europeias, adquirindo ou perdendo prestígio na medida em que divulgava ou não as ideias lá dominantes" (LIMA, 1981, p. 10). Naquele contexto, as repetições de modelos literários a serem seguidos não eram opcionais, e sim uma exigência forçosa dentro de quesitos a serem observados, e obedecidos. Logo, as criações ficcionais eram produzidas de acordo com tais moldes. A narrativa de Caieira contraria as referidas concepções. Assim sendo, o espaço representado na obra não é a corte amaneirada, com jardins e fontes que, provavelmente, deveriam ser os lugares habitados pelo norte-americano, Mr. Filler - antagonista principal da obra -, mas sim o espaço do sertão de Mato Grosso, com todas as suas nuances e selvageria. Por conseguinte, os personagens existentes em suas narrativas também não são donzelas e donzéis portadores de gestos amaneirados e sorrisos amenos, possíveis características dos filhos do norte-americano, ao contrário, são os pobres, pessoas embrutecidas pelo trabalho pesado e pelo sol, destituídos de qualquer sinal de civilização: trabalhadores, negros, homossexuais, velhos - vítimas do esquecimento político e do poder agressor local. Fatos, nitidamente, perceptíveis no seguinte trecho, retirado da obra:

(...) Este doutor coisa nenhuma doutor em desgraça dos outros, doutor em maldição, esse James Filler, sei lá o nome dele, nome de Cão, só pode ser, que aqui, gente dessa terra, ninguém tem nome assim, esse doutor de fel e sangue nos roubou toda essa terra que ele diz que é dele, que ele tem e diz que é sua, e todo esse mundo aí quieto, com medo dele, porque é americano e mora lá na cidade, amigo do governador e de toda essa gentaria importante, passa a vida aproveitando a miséria de todos nós. 


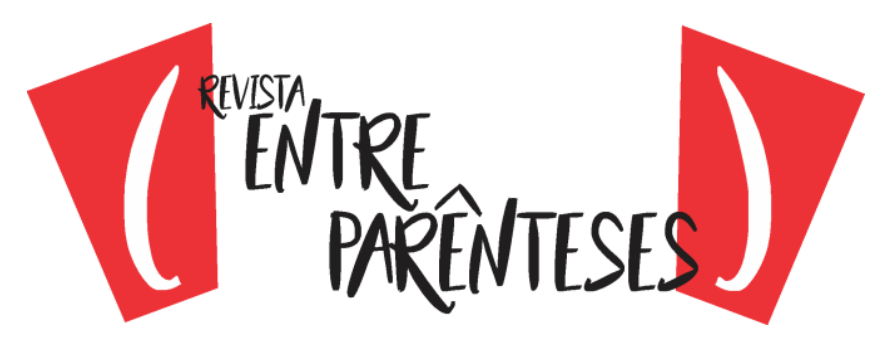

- Cala a boca, velha assanhada, que te destripo, feiticeira do satanás. Se você abrir a boca de novo para falar de gente boa te rasgo essa boca de trapo, de orelha a orelha. E não é só isso, te queimaremos, para que nada sobre daqueles que são filhos do satanás (DICKE, 1978, p.30)

Nessa linha de raciocínio, uma leitura apenas superficial dos excertos referidos, acima, é suficiente para perceber que os sujeitos criados por Dicke e representados, em Caieira, são portadores de um discurso que revela sua condição dramática de marginalizado. São estereótipos daquele espaço geográfico, do contexto em que a obra foi produzida, marcados por dramas sociais; destituídos das mínimas condições humanas, abandonados e distantes da civilização, distante da política, distantes das leis que regem a vida pública e da cidadania de um país que, exatamente, por isso, está muito longe da modernidade. Devido a essas condições, tornam-se objetos, e acabam por se tornarem vítimas do sistema opressor praticado pelos donos do capital local. Para facilitar o entendimento deste raciocínio, é necessário contextualizar em que momento e por que o discurso agressivo apresentado acima se deu.

"Caieira" é o nome do romance e também é o nome da fábrica produtora de cal - "personagem" principal do livro, e tem como gerente e chefe Nheco Salmo homem rude, que se aproveita de sua condição de administrador e, fazendo uso do poder, explora e mata a seu bel-prazer. O proprietário é um norte-americano por nome de Mr. Filler, residente na capital Cuiabá, e que aparece na fábrica apenas, esporadicamente, para buscar o montante do capital produzido durante certo tempo. Mr. Filler se considera "dono de tudo por ali, dono da fábrica, das terras, dos frigoríficos, das pessoas, do município" (DICKE, 1978, p.30). Contudo, a forma como ele enriquece não é nada justa. Um exemplo pode ser observado no discurso registrado no primeiro fragmento, citado mais acima, o qual mostra um desses momentos em que Mr. Filler apropria-se da terra alheia. Trata-se de um diálogo áspero entre os personagens nhá Emerica e o soldado Quilim, este mandado pelo gerente da Caieira. Diálogo que se dá no momento em que o soldado a expulsa de suas terras. Emerica é uma senhora idosa, mora sozinha e nunca fez mal para 


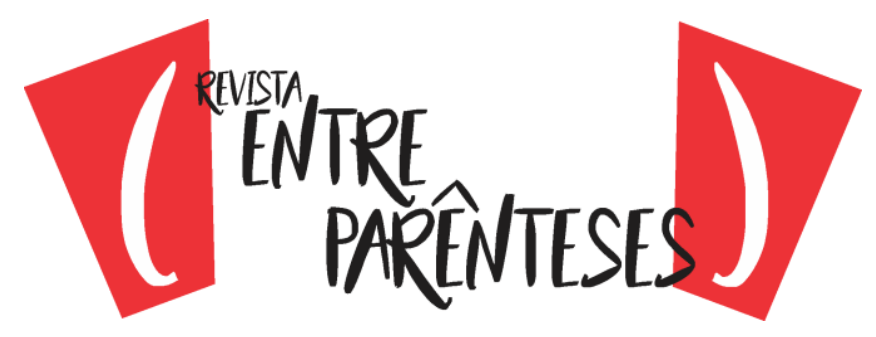

ninguém, mas, quando recebe ordens para abandonar suas terras, não obedece, oferece resistência e é, brutalmente, assassinada num entrecho violento, quando o cabo Quilim a mata, perfurando-a com sabre. Aqui, o nome Emerica é sonoro: parece uma corruptela de América. Emerica, velha, é símbolo da terra americana/brasileira, violentada pelo capital norte-americano, simbolizado por Filler, novo colonizador.

Uma situação típica daquela observada por Homi Bhabha no livro Local da Cultura (1998), quando afirma que "Os embates de fronteira acerca da diferença cultural têm tanta possibilidade de serem consensuais quanto conflituosos" (BHABHA, 1998, p. 21).

Ironicamente, os vários embates existentes na obra Caieira têm resultado tanto consensual como conflituoso. No entanto, em ambos, a minoria (pobres, colonos) sai perdendo. Os homens, quando são rendidos pela força e saem de suas terras entregando-as a Filler, numa suposta conciliação, o fazem por não terem outro meio para sobreviver. Tornam-se empregados do mesmo Mr. Filler na fábrica produtora de cal, sendo explorados e tratados como escravos. As mulheres, por sua vez, ficam condicionadas a mais ou menos duas atividades: se tornam empregadas domésticas, nas casas dos dominadores e, simultaneamente, os satisfazem sexualmente. É o caso da negra Amância, que tinha que se submeter aos caprichos sexuais de seus superiores, sendo explorada ora por Mr. Filler, ora por Nheco Salmo, ora por Damiano, ora por Pio Belo - homens mais importantes do local na escala hierárquica.

Contudo, nem sempre as pessoas se intimidam frente à arma de fogo e às ameaças praticadas pelo colonizador. Os embates, então, se tornam extremamente conflituosos, como no caso aludido acima de nhá Emerica, que embatucou, não quis sair de suas terras e ainda disse verdades incômodas sobre Filler. Emerica morre teimosa e amaldiçoando o soldado que a mata e o chefe colonizador Filler que era o usurpador das terras daquele local. Seu corpo é dado como alimento para os "urubus os quais brigam disputando cada pedaço, e suas terras foram mesmo parar nas mãos do norte americano Mr. Filler. (...) Esta terra é 


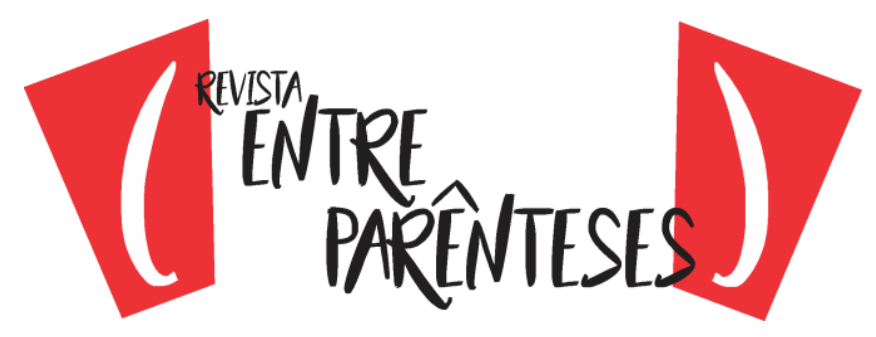

como nenhuma outra. Terra onde os urubus são a sepultura da gente e não o chão" (DICKE, 1978, p.32).

A enunciação marginal descrita acima pode ser entendida, explicitamente, como uma declaração pública do intelectual Dicke, por um lado, a favor dos grupos marginalizados, e por outro, contra o opressor representante do capital. Como se vê, ele está exercendo o papel de mediador e porta-voz de nhá Emerica - como personagem, metonímia da camada marginalizada daquele espaço geográfico. Acaba com isso, tomando uma atitude aos moldes de Sartre (1994), se metendo onde não é chamado: entre nhá Emerica e o poder agressor de Mr. Filler. O que acontece ali é assunto alheio, contudo, Dicke, como um intelectual "engajado", se "mete", para defender os direitos universais que a cidadã nhá Emerica deveria usufruir, como razão, respeito, justiça, liberdade, igualdade - valores iluministas e modernos.

O fato de Dicke se opor ao poder dominante é perceptível na construção do antagonista Mr. Filler, não só na maneira brutal como ele trata os subalternos como também na maneira pejorativa como enxerga o pobre trabalhador rural. Para Filler, pessoas como Emerica eram vagabundas, não prestavam e não trabalhavam. Então, para que queriam terra? "Só ele é o super-homem contra o qual ninguém podia, povo nenhum muito menos aqueles famintos, pobres e rastejantes, miseráveis, hediondos, os ignorantes, os indesejados, eram sub-homens" (DICKE, 1978, p. 32).

Na opinião do norte-americano, o povo tinha que ser seu escravo e para isso não precisava de terras, somente ele era o "afilhado de Deus" e "polícia do mundo". Tal fato faz lembrar a opinião de Bonnici, que afirma: "Quando o colonialismo coloca o nativo no pólo negativo da hierarquia e o associa à categoria do não europeu, ele estabelece sua centralidade e seu poder" (BONNICI, 2005, p. 17). Mr. Filler, homem branco e colonizador, encaixa-se nessa categoria, ele degenera o nativo chamando o de vagabundo cria estereótipos negativos para justificar a invasão, ou seja, a usurpação das terras alheias. Coloca-se como centro do mundo, espécie de deus na floresta do Mato Grosso. Sente-se superior ao 


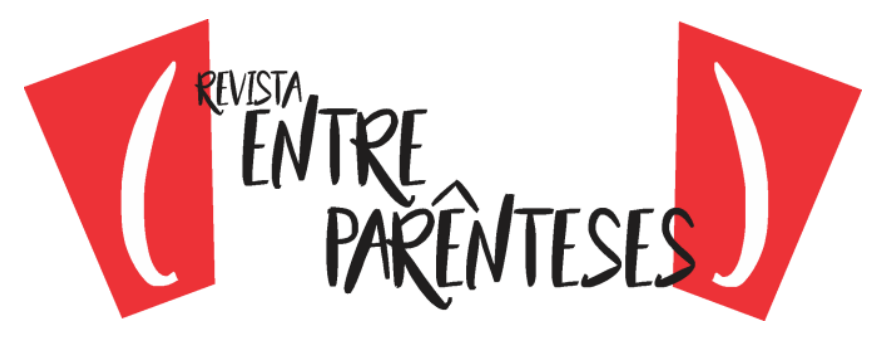

"nativo" e o trata como subordinado. Aqueles que oferecem resistência são mortos, enquanto outros, entregam suas terras e, por não terem aonde ir, como única alternativa de sobrevivência, se tornam empregados da caieira (a fábrica produtora de cal pertencente a Filler). Dobram-se diante do autoritarismo de Nheco Salmo (gerente da caieira), que os obriga a trabalhar horas a fio por dia.

Dicke, ao se posicionar ao lado do colonizado e não do colonizador, encaixa-se no modelo de intelectual que contradiz aquele defendido por Marx. Para ele, artistas e intelectuais modernos, na condição de assalariados, têm seus trabalhos condicionados a servir e favorecer o capital. Esse discurso de Marx se contextualiza na sociedade burguesa, onde quem garantia o ganha-pão dos intelectuais eram os burgueses donos do capital. Nesse caso, de um lado, "a burguesia habilidosa tirava proveito em tudo, obtendo lucro até do pensamento. Por outro lado, os intelectuais, devido a sua situação de encurralados, eram como mercadorias, vendiam-se como se fossem peças" (BERMAN, 1986, p. 113). Transformavam-se em sujeitos objetos, porque estavam subordinados à demanda do mercado e seus trabalhos precisam estar em concordância com as leis e convenções daqueles que os financiam.

As teias e ambiguidades do mercado são de tal ordem que a todos capturam e emaranham. (...) Vendendo-se peça por peça, vendem não apenas sua energia física, mas também suas mentes, sua sensibilidade, seus sentimentos mais profundos, seus poderes visionários e imaginativos, virtualmente todo o seu ser. (...) Os criadores serão incapazes de opor a resistência, pois necessitarão vender sua força de trabalho para continuar vivendo (BERMAN, 1986 , p. 113-4-5)

Essa visão, contudo, não faz jus à realidade das diversas encarnações dos intelectuais ao longo do século XX e inícios do XXI. São inúmeros os papéis do intelectual durante esse período. Ele pode, dentre outros, e inclusive, "ser elite quando necessário, e ser povo quando conveniente" (PÉCAULT, 1989, p. 9). Não que seja um hipócrita - mas é preciso reconhecer aqui a gama ampla de intelectuais reais que esse período conheceu. Fato que pode ser visto no trecho de Beatriz Sarlo, a seguir: "Por vezes, empregaram seus saberes no embate com os ricos e 


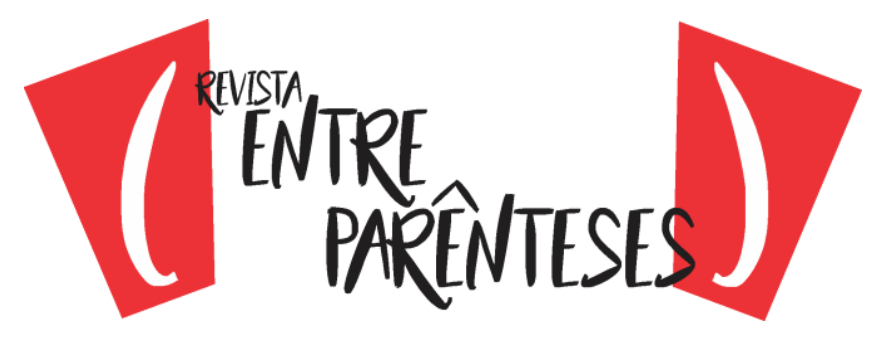

com a autoridade; outras vezes, o empregaram para impor seus pontos de vista sobre os desvalidos" (SARLO, 1997, p. 158).

Nesse caso, Dicke corrobora com o perfil de intelectual defendido por Pierre Bourdieu. Este, ao escrever um ensaio sobre o papel do intelectual no mundo moderno, assevera que eles, por conviverem, desde seu surgimento, em oposições da cultura pura e do engajamento, são pessoas bidimensionais, estando subordinados a duas condições.

(...) De um lado precisam pertencer a um campo intelectualmente autônomo, independente do poder religioso, político, econômico e outros, e precisam respeitar as leis particulares desse campo; de outro lado, precisam manifestar sua perícia e autoridade específica numa atividade política exterior ao campo particular de sua atividade intelectual. (...) quanto maior a independência do intelectual com relação a interesses mundanos, advinda de sua mestria, tanto maior sua inclinação a asseverar essa independência, criticando os poderes existentes, e tanto maior a efetividade simbólica de qualquer posição política que possam tomar (BOURDIEU apud CHAUÍ, 2006, p. 20)

Pertencer a um campo intelectual autônomo significa poder ser do "contra", tendo a oportunidade de se posicionar ao lado e em defesa do oprimido e isso é o que aparece configurado na obra Caieira, pois nela é dada "voz" aos silenciados e subalternos. Nesse caso, Dicke, por meio das construções discursivas presente em Caieira, está conforme o que teoriza Said, quando afirma que o intelectual "deve levantar questões embaraçosas, confrontar ortodoxias e dogmas, não se deixar compactuar com governos e corporações e, com isso, apresentar problemas que são sistematicamente esquecidos, e jogados debaixo do tapete" (SAID, 2005, p. 23).

Nesta mesma vertente, Antônio Candido conceitua o intelectual e o artista como opositor: "seu lugar é no lado esquerdo da ordem estabelecida; sua natureza é adotar uma posição crítica em fase dos regimes autoritários" (CANDIDO, 1989, p. 194). Conivente com tais pensamentos, a literatura praticada por Dicke valoriza a heterogeneidade típica de lugares de fronteira e, com isso, subverte o discurso oficial hegemônico. Ao posicionar-se dessa forma, o autor, sistematicamente, se 


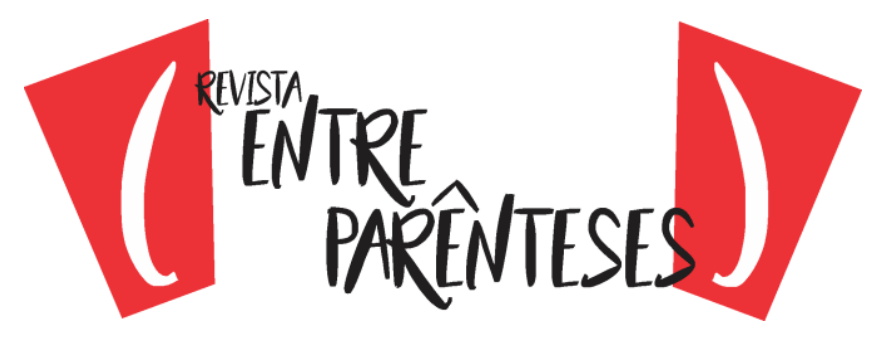

torna um exilado, no sentido de não compactuar com as narrativas tradicionais que, nas quais a cultura europeia prevalece como superiora e como modelo.

De acordo com o referido pensamento, é preciso ressaltar que a ideologia presente na construção do imaginário das narrativas do intelectual Ricardo Guilherme Dicke assemelha-se à de Graciliano Ramos, Guimarães Rosa e outros os quais abriram mão da concepção cultural eurocêntrica, rejeitando a cultura europeia como centro motor de suas narrativas. Ao trazerem para o centro as vozes da cultura e dos segmentos culturais periféricos, os referidos escritores contribuem para que "a criação dos artistas latino-americanos não seja reduzida à condição de parasita, obra que se nutre de outra sem nunca lhe acrescentar algo próprio; obra cuja vida é limitada e precária" (SANTIAGO, 2000, p. 18).

Deste modo, em Caieira, o sertão e a seca tomaram o lugar das cidades com seus palácios amaneirados; as vestimentas maltrapilhas tomaram o lugar dos vestidos bordados, luvas, chapéus e casimira; a brutalidade, a ausência de letramento e sofisticação tomou o lugar das falas e dos gestos sofisticados, como é o caso da nhá Emerica, que, devido a sua condição de silenciada, necessitava de um porta-voz.

Assim sendo, a opção de ter as vozes da margem como locus de enunciação, mesmo na ficção, sugere o esforço dickeano em legitimar a cultura periférica de Mato Grosso, justificando que esses indivíduos não produzem não porque sejam vagabundos, e, sim, porque são vítimas de um sistema capitalista opressor, como se vê no exemplo retirado da obra: "gente que ali entrava para trabalhar para o americano não saía mais. Podia sair sim, mas de uma hora para outra poderia não mais ver a luz" (DICKE, 1978, p. 137). Sem ter outra opção de vida, os empregados da Caieira iam vivendo "entre lágrimas e espirros, vivendo como mortos-vivos, feito estátuas transfiguradas" (DICKE, 1978, p. 137).

É preciso acrescentar que a decisão do intelectual Dicke em ficar do lado dos mais fracos está de acordo com o perfil defendido por Sartre. Ao falar sobre o lugar que deve ocupar o intelectual, Sartre, em suas prescrições, sugere que o mesmo deve se decidir por ficar em um determinado lugar. Mas ele critica, 


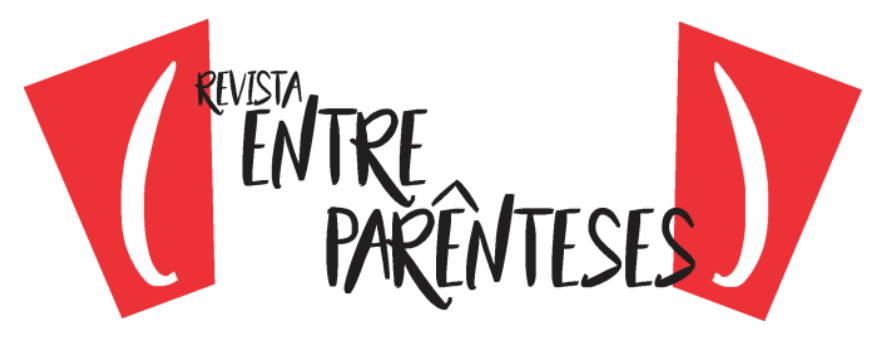

ferozmente, aqueles que estão do lado do humanismo burguês. Afirma que a primeira tarefa de um intelectual é ter consciência de sua contradição. Contradição que se verifica por ser o intelectual um ser dividido entre ideologias particulares que condicionam sua vida, como: (fatores econômicos, sociais e culturais), e universalismo (exigência intrínseca da sua atitude como técnico e pesquisador).

Sartre afirma ainda, que os intelectuais não podem ser neutros diante da realidade histórica e social. Precisam ter responsabilidades, tomar partido diante dos dilemas de seu tempo, não se abster da participação na política. Para ele, a "palavra" é "arma" fundamental do intelectual, significa ação. Nesse sentido, a tarefa de um intelectual não é só interpretar o mundo e sim transformá-lo. Dicke não é como Sartre, que intervinha na realidade através de ações, adentrando na cena pública diretamente, empunhando até megafones. Dicke intervém, indiretamente, na realidade, silenciosamente, por meio da ficção, criando, por exemplo, personagem como o Pignon, presente no romance Caieira, o qual analisaremos a seguir.

Tal leitura será feita numa perspectiva crítica, a qual enfatiza um contexto marcado pelo horror, em que os sonhos, projetos, posicionamentos políticos e ideológicos do personagem simplesmente não existem, foram apagados devido ao processo de servidão e escravidão sofrido durante sua existência. Contudo, mesmo em sua condição de silenciado, ele, através da única arma que possui - domínio e conhecimento da natureza -, provoca a reviravolta. Faz com que os acontecimentos, no desfecho, tomem rumos contrários. O fato se concretiza numa configuração que pode ser entendida como a objetivação da vontade subjetiva e individual do escritor em resolver antagonismos que só são possíveis de serem resolvidos na ficção. Fato que será retomado no final desse artigo.

A solução ficcional de Dicke encontra eco na teoria de Adorno. Para esse autor, "os antagonismos não resolvidos na realidade retornam às obras de arte como problemas imanentes da sua forma" (ADORNO, 1970, p. 16). Dicke conserva, na estrutura do romance Caieira, esses antagonismos sociais não solucionados na realidade. Mas, por não ser um mero espectador do mundo que o rodeia, por ser engajado no sentido de não produzir uma narrativa ociosa nem passiva, procura dar 


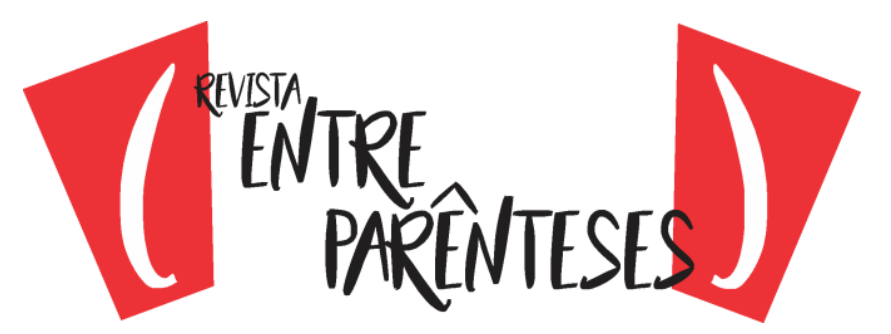

cabo a esses antagonismos no fechamento da narrativa, numa atitude que contrapõe a ideia defendida por Lukács (2000, p. 66-7). Para este, no romance, a oposição entre realidade e ideal se traduz em uma tensão entre o desejo e a impossibilidade da realização do mesmo. Para Lukács, o bom romance é aquele que apresenta os problemas, porém não os soluciona, assim como é na realidade. No entanto, outra vertente defende "que o romance não tem regras nem freios, sendo aberto de todos os possíveis, de certa forma, indefinido de todos os lados" (ROBERT, 2007, p. 140).

Mas, vamos ao personagem Pignon. Quem ele é?

Trata-se de um sujeito que aparece, misteriosamente, dentro da obra. Ele, assim como Amância, é negro, marginalizado e silenciado dentro do enredo. É alguém que impõe admiração, de um lado, e medo do outro. Nas mulheres provoca os mais intensos desejos íntimos, contudo, nos homens causa tanto inveja como temor, principalmente naqueles que detinham o poder. Ele é diferente dos demais moradores daquele lugar, não aceita ser subordinado a Nheco Salmo, muito menos a Mr. Filler. Sua independência se opõe à de homens como Calvário, Comissão, Clemente e Belisário, este último, funcionário da caieira, que, pelo trabalho insalubre da fábrica, sofre de tuberculose e vomita sangue preto.

Pignon é um gigante negro. Tem o corpo entrecruzado de cobra. Os pulsos e tornozelos apresentam marca das argolas de ferro, sinais que ficaram das violências que sofreu na prisão. E em uma das pernas possui uma pulseira que não conseguiu serrar. Sinal que o oprime e faz paralisar seu sangue, porque o faz lembrar, constantemente, das humilhações que sofreu no passado.

Pignon, assim como nhá Emerica, também é vítima do sistema opressor local. Mas ele reage no momento em que é agredido pelo sargento Jeanot, agente do sistema opressor local. Diz Jeanot: "os pretos não são gente e só servem como escravos para substituir os animais" (DICKE, 1978, p. 118). Pignon revida, recuperando sua dignidade: dá uma lição no sargento, matando-o e urinando em sua cabeça. Jeanot, contudo, não morre sem reagir, e essa briga acaba deixando sequelas no corpo de Pignon. Sua face é aberta pelo meio, nela as cicatrizes são 


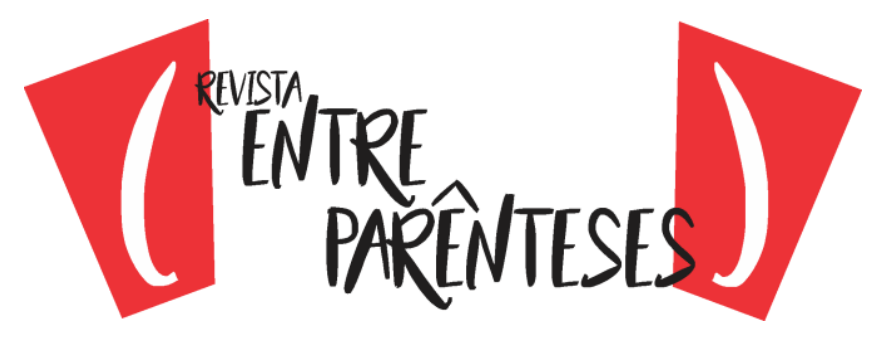

monstruosas: um dos olhos se exibe cortado pela metade, e no rosto há um buraco que exibe os ossos brancos. Por isso, Pignon "respira pela abertura sibilante da face esquerda, por onde aparecem os dentes e seu rosto tem a aparência de um cavalo negro" (DICKE, 1978, p. 119). Pignon demonstra insatisfação com sua aparência e, frequentemente, manifesta desejo de mudar a fisionomia, se pudesse, o faria.

Vive escondido nas matas, próximo da fábrica produtora de cal, e faz o possível para que ninguém o veja. Vive tranquilo, seguro de que ali ninguém mais se lembre dele: "talvez pensassem que já era estrume de tubarões ou punhado de ossos em algum pântano sujo" (DICKE, 1978, p. 119). Sai, às vezes, da selva, porém "sorrateiramente, passando pelos atalhos, esgueirando-se no mimetismo das matas" (DICKE, 1978, p. 116). Contudo, de vez em quando, uma ou outra pessoa o vê. E a opinião que prevalece, entre elas, é a de que se trata de um "doido ou alguma múmia fantasmagórica, entidade amiga das cobras ou algum feiticeiro perdido" (DICKE, 1978, p. 116).

No entanto, num determinado dia, quando o corte na face provoca muita dor, ele sente medo de enlouquecer. Sua carne arde tanto que parece que seu corpo está em chamas de tanta febre e então sai sem rumo andando por lugares disparatados. "Descontrolado não vê por onde anda, onde está, por onde passa. Só sombra, ruídos, vozes" (DICKE, 1978, p.121). De repente, sem noção, adentra a casa do gerente da Caieira.

Nheco Salmo, ao se deparar com aquela figura gigantesca e negra na porta de sua casa, fica imóvel na cadeira. "Gelado de susto pensa que se trata de algum fantasma, ou alguém inimigo desses que havia acumulado pelo longo da vida. Fica tão descontrolado que os papéis em suas mãos caem e se espalham pelo chão" (DICKE, 1978, p. 121). Seu queixo treme, o corpo pesa como chumbo. Quer chamar alguém, mas a voz não sai. Levanta, derruba a cadeira e foge pela janela, caindo entre os arbustos do jardim. Levanta-se berrando, chamando por socorro. Aparecem os funcionários da Caieira, e ele, escondido num canto do jardim, dá 


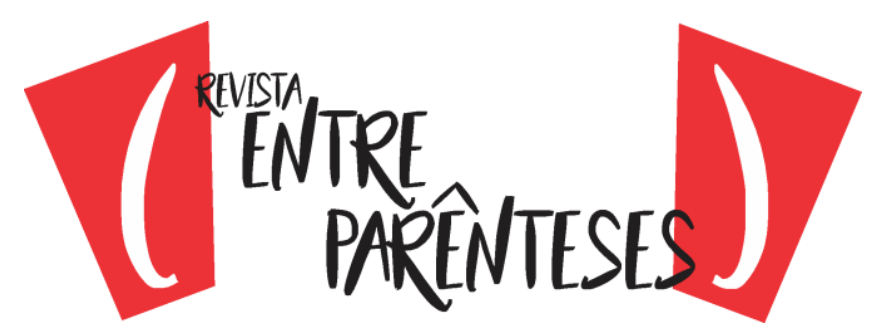

ordens para que seus súditos capturem e matem o desconhecido. Tudo em vão, visto que Pigmon desaparece.

Nheco Salmo continua totalmente descontrolado, trêmulo e hirto de histeria, grita, fora de si, continua dando ordens aos seus empregados. Avisa que aquele que o visse, novamente, rondando a caieira e a Boa Esperança estava autorizado a tocar bala, tinha certidão sua para atirar e matar.

Diante do estado de descontrole de Nheco Salmo ao se deparar com a figura de Pignon, algumas perguntas surgem em busca de justificativa para tal situação de medo: será que se deve ao tamanho de Pignon? Ou porque Pignon é anticapitalista? Ou porque era alguém seguro de seu locus, consciente de sua condição de subalterno e, por isso, poderia tomar o lugar dele? Ou por que o reconheceu como uma de suas vítimas?

Nheco Salmo, de observador, passa a ser observado. Treme, sobretudo, porque alguém, apesar de ser da fronteira, tem consciência do seu lugar. E que, devido a sua condição de subalterno, chama a atenção do colonizador. O que será que ele tem? Perguntava Nheco Salmo a si mesmo. Situação semelhante àquela teorizada por Fanon, quando se refere ao comportamento entre nativo e colono, convivendo no mesmo espaço: "Quando seus olhares se encontram, ele (o colono) verifica com amargura, sempre na defensiva, que 'eles querem tomar nosso lugar'. E é verdade, pois não há um único nativo que não sonhe pelo menos uma vez por dia se ver no lugar do colono" (FANON apud BHABHA, 1998, p. 16). Pignon tinha consciência de suas limitações por ser alguém do entre-lugar, por isso sabia onde pisava, e passou a representar perigo e ameaça ao poder local estabelecido.

É o que afirma o filósofo do século XVI chamado Etienne de la Boétie, num pequeno livro, O discurso da servidão voluntária. Quando um indivíduo manda, seu poder vem não dele mesmo, mas dos outros que se submetem. O que sustenta o tirano não é a sua própria autoridade, mas a entrega dos súditos, isto é, a dominação só é possível com o consentimento dos próprios dominados. Disso se conclui que o poder de um só existe, se o outro permitir. 


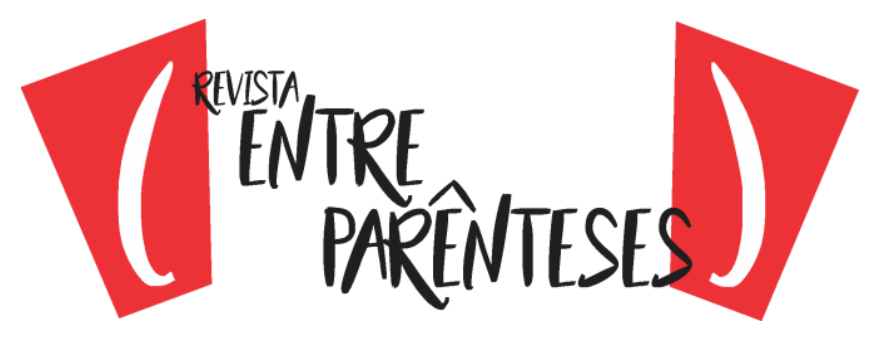

Nheco Salmo tem medo, porque sabe que seu poder é soberano enquanto houvesse pessoas pacatas como os funcionários da Caieira, os quais permitem ser oprimidas e marginalizadas. Mas, com relação ao aparecimento de Pignon, o qual impunha respeito até pela maneira de andar e encarar, será que seu poder continuaria? Não, pois ele ficou nitidamente ameaçado com o aparecimento de Pigon que mesmo fazendo parte de um sistema de "coisificação" do ser em sua revolta era sufocada constantemente e seu poder de ação no mundo niilizado, consegue a reviravolta dando a volta por cima, utilizando um recurso fundamental que é a esperteza e a inteligência. Fato que será detalhadamente mostrado adiante.

A construção de Pignon é projeto pessoal do intelectual Dicke, como materialização individual de seu desejo de denunciar, desmascarar o sistema opressor local e, ao mesmo tempo, fazer justiça. Ainda que o romance não tenha obrigação nenhuma de "tomar" ou "devolver" algo sobre a realidade de um povo ou nação, ainda assim, como sabemos, ele não é uma prática inútil, "pois embora a realidade Ihe seja para sempre inacessível, ele a toca, apesar disso, sempre num ponto decisivo, figurando no desejo real de mudá-la. Quem faz um romance exprime com isso o desejo de mudança" (ROBERT, 2007, p. 28).

A operacionalização da ação intelectual engajado do escritor Dicke se dá através da palavra escrita na criação de personagens, como por exemplo, Pignon e Amância, cuja representação descreve a trajetória desumana e brutal pela qual passaram. Ambos são afrodescendentes e semiescravizados, habitantes do suposto território de Mato Grosso, num espaço chamado Boa Esperança. São exilados não só geograficamente, como também culturalmente, e, nesse caso, são desprovidos de atributos mínimos, como a voz. Contudo, Dicke resolve emancipá-los, criando na narrativa uma situação em que favorece a possibilidade de "revide". Com isso, ambos, tanto Pignon como Amância, de "objetos" passam a ser "sujeitos". Dessa forma, o autor, através dessa construção imaginária, contraria o cânone literário hegemônico ocidental, masculino e branco.

\footnotetext{
${ }^{4}$ Reduzir (o ser humano, ou elemento(s) ligado(s) a ele) a valores exclusivamente materiais.
} 


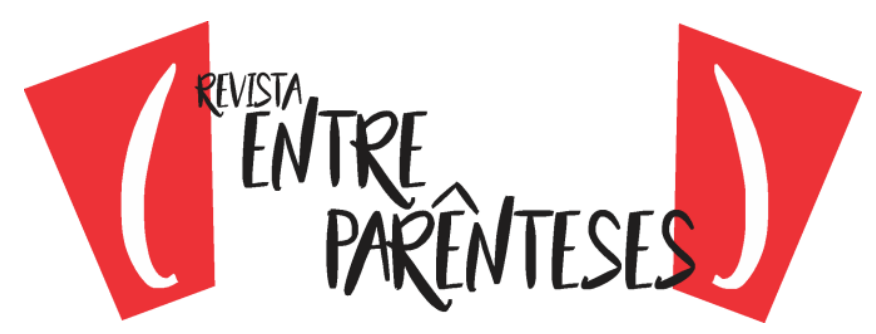

O revide ou a resistência foi um dos recursos criados por Dicke, dentro da narrativa, como maneira de fazer com que aqueles sujeitos insatisfeitos e oprimidos se livrassem do poder opressor que Ihes era imposto. Veremos a seguir como tal fato se dá na obra Caieira.

O proprietário da caieira, Mr. Filler - com a boca cheia de dentes de ouro -, costuma vir a Boa Esperança esporadicamente, com o objetivo de recolher o capital produzido, passear no rio, pescar e abusar sexualmente das mulheres que trabalham na caieira, trata-as como sua propriedade.

Na última vez em que lá chega, traz em seu caminhão uma bela lancha especial e recentemente vinda dos EUA. Nessa mesma tarde, exige que Nheco Salmo, na condição de gerente da caieira, como era de costume, arrume-lhe uma mulher. Desta vez, sobe em sua lancha, para lhe fazer companhia, a negra Amância. O norte-americano dialoga consigo mesmo, gabando-se:

O que alguém tão ilustre pede, nem se hesita em oferecer. Homem tão nobre merece, não precisa nem pedir. Para que servem mesmos estes negros, se não for para isso? São proprietários deles. Um dia minha, outro dia do patrão. (DICKE, 1978, p.216)

Mr. Filler, aparentemente, demonstra estar muitíssimo satisfeito, "nunca tinha, antes visto, rio tão bom de pescar e mulher tão boa de amar" (DICKE, 1978, p.217). Consegue, em pouco tempo de pesca, fazer com que o fundo da lancha se encha de peixes grandes, pescados, pacus, pirapitingas. Enquanto isso, "Amância continua do mesmo jeito que entrou, silenciosa, nua parecendo uma Afrodite, continua deitada no convés". "Ela demonstra indiferença completa a tudo que ocorre em sua volta" (DICKE, 1978, p. 217). Inclusive, não apresenta nenhum tipo de movimento em seu rosto, e, desde que entrou na lancha, sua única ação foi satisfazer sexualmente o norte-americano.

Tudo estava indo muito bem até a lancha se enroscar em troncos afundados e em raízes enormes presentes no rio, os quais fizeram com que a lancha nem saísse do lugar. 


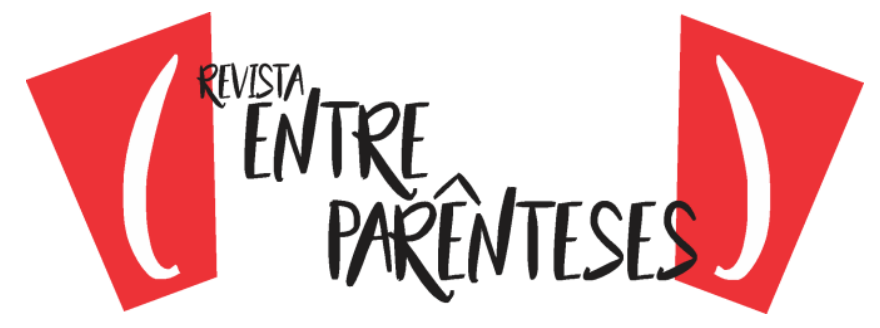

(...) Suado sob a cabine, Mr. Filler vê nas margens um canalzinho que entra rio adentro por um intrincado de arvoredos marginais de jatobás gigantescos e centenários de raízes enormes que pendem dos barrancos e encobrem o azul e derramam sombra no remanso e tristes imbaúbas que espalmam os dedos através das folhagens, como mãos abertas de dedos hirtos. (...) pendem dos ramos das árvores inumeráveis cipós, uma floresta de cordas, aquele cipoal vermelho caindo a pique na água de abas frondosas das massas escuras e rumorejantes. (...) dirige a "ranger" para lá, mas logo vê que não vai dar passagem, faz uma curva, quer voltar, mas logo se atracou e a prende, o motor geme, acelera tudo o que dá, mas a bichinha não sai do lugar, tenta de novo e nada, mais uma vez e mais outra e sempre nada. Parece que um tentáculo a agarrou lá embaixo pelas hélices, os tentáculos de um polvo monstruoso e não sai. Serão troncos afundados, raízes enormes, emersas (DICKE, 1978, p. 218)

Nesse momento, a natureza parece personificar-se. Arma uma revolução para prender o norte-americano: "troncos e raízes revolucionam em engruvinhos e emaranhados impressionantes e coleiam em mil variedades de nós na vermelha profusão apavorante dessa natureza altiva, traiçoeira e rebelde" (DICKE, 1978, p. 217).

Desesperado, Mr. Filler, ao perceber que estava prestes a ser emparedado pelos troncos, raízes e cipós, pede socorro para Amância. Ela não responde. Finge que dorme. Sem alternativa, pois nem ao menos sabia nadar, ele senta na beira da lancha e começa a fumar, nervosamente, um cigarro atrás do outro.

Amância, como nasceu e cresceu naquela região, conhece muito bem aquele rio e sabe tudo sobre ele, sobre os matos, sobre os caminhos perdidos e, com certeza, possui embasamento prático suficiente para resolver a situação, mas, propositalmente, ignora todos os chamados do dono da Caieira. Quando escuta os gritos de Mr. Filler, simplesmente, ignora-os, faz de conta que não os ouve, fecha os olhos e finge dormir.

Mr. Filler, preocupado, olha as horas no relógio de ouro em seu pulso. Percebe que o sol está se pondo, e se arrepia ao pensar na ideia de ter que passar a noite naquele lugar. 


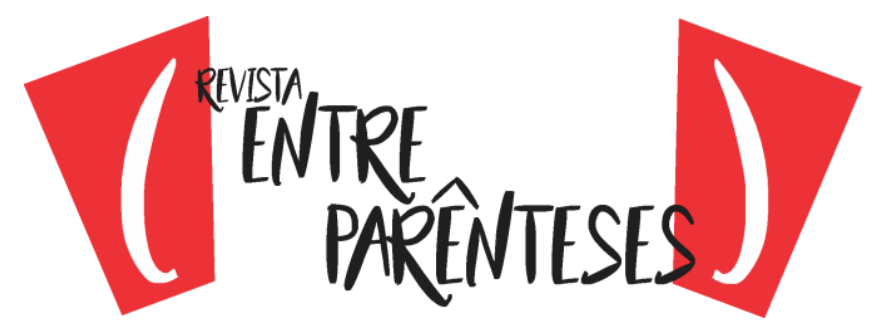

Contudo, um par de olhos lhe observa atentamente pelas costas: de repente, sem que ele perceba, "um braço negro se ergue do lado de fora, dentro do rio e põe qualquer coisa dentro do convés. $\mathrm{O}$ musculoso braço se retira sem ruído. $\mathrm{O}$ par de olhos se esconde sem bulha, não se ouve ninguém nas águas" (DICKE, 1978, p. 219). Amância, ao ver a cena, sorri, satisfeita.

Mr. Filler, ao observar lindas orquídeas que, juntamente com os cipós, caem dependuradas em volta da lancha, resolve apanhá-las para levar a sua esposa Sally, que o espera em Cuiabá. Contudo, ao pegar num galho para abaixá-la, "sente um cipó que se mexe e se lhe escorre pelo braço como uma coisa viva, um rabo comprido e fino, salta e chicoteia-Ihe o rosto e, instantaneamente, um queimor perfura-Ihe o alto da cabeça, na calva, em cima da orelha" (DICKE, 1978, p. 220).

Olha surpreendido uma pequena cobrinha verde de riscos laranja que corre em ziguezague pelo soalho, logo sobe por um cano, trepa por uma ponta oscilante de cipó e rapidamente, traiçoeiramente desaparece. Mr. Filler leva a mão à cabeça, retira-a manchada de alguns pinguinhos de sangue (DICKE, 1978, p. 220)

Ao perceber que foi picado e já tomado pela dor grita, berra corre pelo convés, mas já se enfraquecendo a voz que morre sem ecos dentro dele, cala-se olha para a carabina em busca de consolo, de socorro, olha com os grandes olhos arregalados para a mulher, mas esta se deita de novo e olha o céu (...) sem mais conseguir ficar de pé, deixa-se cair sobre os peixes. Os olhos se embaralham, a cabeça arde, respira pesado, pinga sangue da boca, narinas e ouvido enquanto isso os peixes atacam mordendo seus dedos, língua, corpo (DICKE, 1978, p. 220)

De repente, um rumor dentro do barco lhe chama atenção. Faz um enorme esforço e consegue abrir os olhos. Vê, em sua frente, uma espécie de gigante negro. O gigante é Pignon, o qual dança, animadamente, com suas cobras ao redor do pescoço. Tira a peixeira da cinta e a abaixa, encostando-a na garganta do americano, mas a mulher o chama. Então, ele guarda a faca e cospe em cima da cara do americano. Pignon e Amância descem da lancha, nadam até a margem, deixando Mr. Filler morrer sozinho. De longe, observam a morte, silenciosa, daquele que se dizia dono de tudo por ali. 


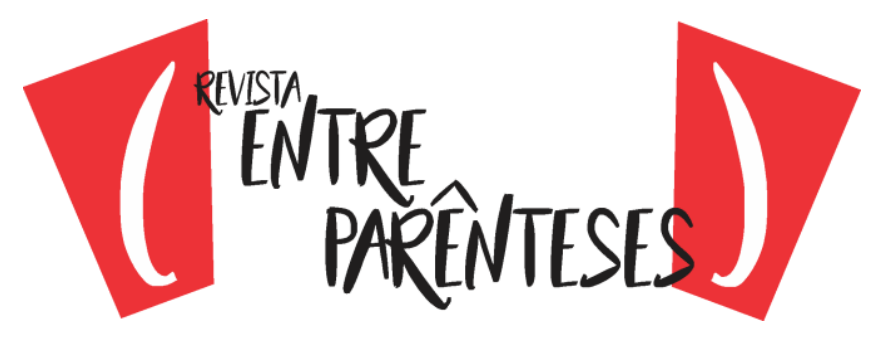

Enquanto isso, a cabeça da vítima fica negra, só os olhos piscam muito lentamente, mas mesmo nessa situação pensa: "Eu o dono de tanta coisa, de tanta indústria, desta terra, morrer assim, como um peixe engasgado, envenenado"? (DICKE, 1978, p. 221).

Seu cadáver, após ser encontrado, é colocado em cima de uma mesa, num cômodo sujo, no fundo da Caieira. Rígido e arroxeado, passa a noite inteira sozinho, sem nenhuma companhia. No início até que chama a atenção, mas depois ninguém mais vem vê-lo.

Depois de alguns dias, é levado para a capital Cuiabá, onde reside sua família, para ser enterrado.

Nheco Salmo, angustiado e infeliz, desaparece do local, do dia para a noite.

O Suposto diabo Negro, no dizer de Nheco Salmo, passa a ser o dono não só da Caieira, como também das três mulheres mais importante do local. Da Amância, da Almira - filha de Nheco Salmo - e também da Sally - viúva de Mr. Filler.

Nesse fechamento, a alegoria mencionada acima se efetua - a morte do norte-americano, em oposição à vitória do nativo, pode ser entendida, numa configuração emblemática, como uma metáfora da ideologia subjetiva do próprio intelectual Dicke, de querer fazer justiça. Ele, através do imaginário, demonstrou seu repúdio e asco frente aos desmandos e violência praticado pelo norte-americano. Metaforicamente, o ajuste de contas foi feito. Nesse aspecto, Dicke corrobora com a opinião de Octávio Paz, que afirma: "Uma literatura nasce sempre frente a uma realidade histórica e, frequentemente, contra essa realidade" (PAZ, 1972, p. 126). Fatos perceptíveis na construção do revide demonstrado, onde Pignon permite que uma de suas cobras adentre a lancha e pique o norte-americano, num entrecho silencioso, porém eficiente. O revide redimensiona, amplamente, seu significado, quando Pignon toma o lugar do norte-americano, não só na fábrica produtora de cal, como também na cama, satisfazendo os desejos mais íntimos daquela que tinha sido esposa do norte- americano. 


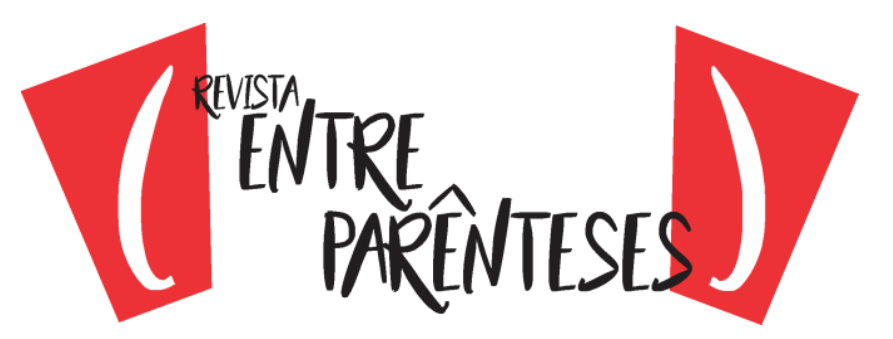

Através da ação silenciosa do negro Pignon, como apresentado, Dicke coloca por terra a superioridade do "colonizador", e do branco como "raça pura", e eleva o nativo, o negro, emancipando-o a ser sujeito, pelo menos dentro das narrativas subalternas.

A ação da Amância de fingir que aceitava a companhia de Mr Filler faz lembrar a "civilidade dissimulada" discutida por Homi Bhabha (1998), em que o suposto nativo faz aquilo que se espera e age de acordo com as regras estabelecidas. No entanto, dentro do seu ser, planeja o revide, o contra-ataque. Logo, Amância, para poder resistir, faz de conta que aceita o que lhe é imposto, para poder negar no momento apropriado. Com a "civilidade dissimulada", Amância, na sua condição de oprimida, ganha tempo e força para, na hora do "combate", fazer o que fez, sem que o opressor, Filler, perceba.

Nessa linha de pensamento, também se verifica a "cordialidade", mas não a do cortês e sim a cordialidade da sobrevivência. Amância se mostra equilibrada, através da máscara, se ajusta na imposição que vem de cima para baixo para poder sobreviver, na confiança de que haveria uma hora em que poderia agir. De acordo com Silviano Santiago, "A máscara brasileira mostra o retorno das tradições nativas do mundo contemporâneo para que o homem moderno possa recarregar as baterias da sobrevivência. (...) máscara é censura velada, é recalque" (SANTIAGO, 2006, p. 223). Foi uma forma encontrada por Amância como estratégia de defesa contra as hostilidades, as transgressões e os maus tratos vividos durante sua existência. Através do disfarce e subterfúgio, ela conseguiu tirar aquele povo das amarras opressoras do norte-americano. O crítico ainda menciona que "A cordialidade é uma arma, é uma peça de resistência, é a defesa do indivíduo contra a sociedade" (SANTIAGO, 2006, p. 246).

Amância sabe utilizar tais recursos para poder sobreviver até o revide. Contudo, o mesmo não acontece com nhá Emerica, pois não dominava a técnica desses subterfúgios; se soubesse utilizar tais estratégias, talvez não teria morrido.

Homi Bhabha (1998), fala da mímica colonial como um "desejo por um outro reformado, como sujeito da diferença que é quase o mesmo, mas não 


\section{("EATRER}

exatamente" (BHABHA, 1998, p. 130). Seu discurso é produzido em cima da ambivalência:

A ambivalência da mímica - quase, mas não exatamente - sugere que a cultura colonial fetichizada é potencial e estrategicamente uma contra-apelação insurgente. (...) Sob o disfarce da camuflagem, a mímica, como o fetiche, é um objeto parcial que radicalmente reavalia os saberes normativos da prioridade da raça, da escrita pois o fetiche imita as formas de autoridade ao mesmo tempo que as desautoriza (BHABHA, 1998, p. 152-154)

Conforme o autor, para ser efetiva, a mímica "deve produzir sempre seus deslizes, seus excessos, suas diferenças" (BHABHA, 1998, p. 130). Amância, por exemplo, para sobreviver, mostrava sempre não o "eu", e sim o "eu" fingido, de acordo com a convenção eurocêntrica. Aparentemente, era uma mulher pacata como as demais, "cabeça baixa". Vivia apenas para servir os homens da caieira. Era a cópia da mulher daquele lugar, porém não exatamente. A diferença se manifestou no fato dela ter armado um plano para se livrar do opressor e se sair vitoriosa. Com isso, deixou de ser mulher-objeto como as demais e se transformou em sujeito.

De acordo com Bhabha (1998, p. 131), a mímica é ambivalente, porque trai a identidade própria do colonizador, porque copia a identidade do outro. Amância e Pignon copiaram a identidade do norte-americano: maldade, frieza - porém, não traíram sua identidade, porque foi apenas por alguns momentos, apenas 0 necessário para provocar o revide. Amância teria traído, se tivesse subido no barco, se vangloriado por estar ao lado do todo poderoso, esperado por ele outras e outras vezes, sonhado com casamento, etc. Pignon, por sua vez, teria traído sua identidade, se tivesse, por exemplo, esperado ganhar um emprego de confiança, etc. E, assim sucessivamente.

A mímica é como uma camuflagem, não uma harmonização ou repressão da diferença. (...) A mímica não apenas destrói a autoridade narcísica pelo deslizamento repetitivo da diferença e do desejo. É o processo de fixação do indivíduo colonial como forma de saber transclassificatório, discriminatório (BHABHA, 1998, p. 136) 


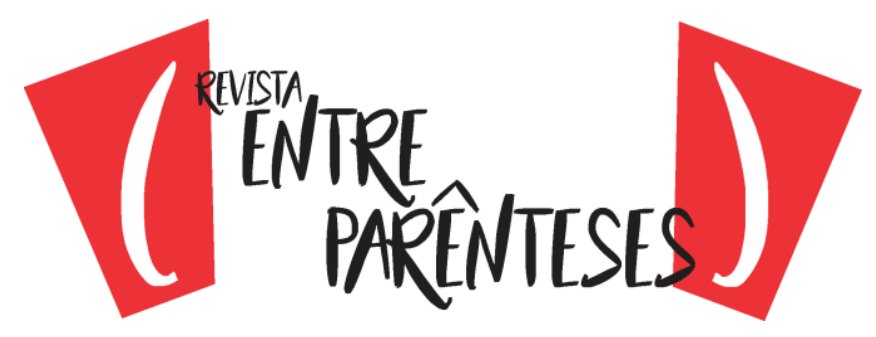

O autor ainda fala que a mímica pode ser, simultaneamente, semelhança ou ameaça. Semelhança, porque imita o inimigo, fazendo tudo igual a ele, e consegue sua confiança. Ameaça, porque, quando chega a tomar o lugar do outro, mostra a verdadeira cara e coloca os planos para funcionar. Pignon, ao ser o novo dono do espaço Boa Esperança e da Caieira, acabou por tomar o lugar do colonizador, mas não esqueceu sua proposta inicial, e com isso não repetiu o mesmo sistema autoritário de trabalho, foi diferente, fez do seu jeito.

\section{Considerações finais}

No presente artigo tivemos a intenção de mostrar, dentro do romance Caieira, a posição do intelectual Dicke como alguém comprometido com as questões sociais do seu tempo. Por um lado, a obra mostra a imposição que vem de cima, o colonizador e tudo que ele representa; por outro, mostra os seres humanos vítimas de maus tratos praticados pelo poder agressor local dono do capital. Oposições, enfatizadas nas representações ficcionais, as quais apresentam conceitos e características que comprovam Dicke como um intelectual contemporâneo, um exilado, um sujeito à margem devido à distância das narrativas tradicionais de supremacia ocidental cristã, branca, patriarcal que prevaleceram até meados dos século XIX, em que as representações dos afrodescendentes estavam sempre condicionados a papeis subalternos, sempre servindo o branco cordialmente, sem contestar. Desta forma, o romance Caieira estabelece relação com os conceitos subalternos presentes na literatura pós-colonial como, resistência, revide, mímica, civilidade dissimulada, subversão, etc.

Assim, percebe-se que os personagens do romance Caieira enfrentam problemas os quais possuem raízes ligadas à exclusão. Exclusão que se deve em grande parte ao fato de estarem condicionados aos desmandos do colonizador, representado por Mr. Filler, o qual não aceitava o "outro" - eles - como sujeitos. Uma forma de a referida exclusão ser evitada seria se a mente de Mr. Filler passasse por um processo de "descontaminação", fato impensável devido à 


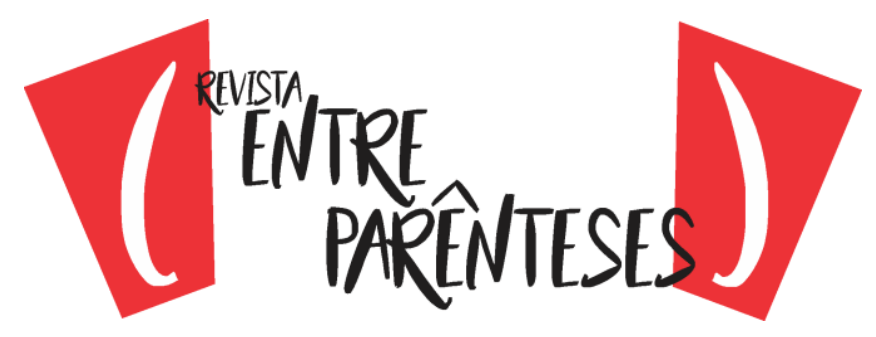

concepção ideológica e cultural que fez parte de sua formação e está impregnada em suas atitudes.

O comportamento de Mr. Filler faz jus ao fato de que somente a civilização euro-americana era considerada válida e, por isso, nem cogitava em aceitar a diferença. Consequentemente, como é de praxe acontecer com o "outro", o negro Pignon e Amância foram reificados pela cultura norte-americana, contudo, usando da "máscara" e outras estratégias consideradas como revide, como "a mímica", a "civilidade dissimulada", aproximaram-se do colonizador branco. No entanto, ao contrário do que normalmente se esperava, eles não perderam sua autoestima, nem se aceitaram como inferiores. Usaram da referida estratégia para fazer o "revide". E, com isso, tomaram o lugar de Mr. Filler. Expulsaram Nheco Salmo, fato que possibilitou aos sujeitos daquele lugar serem livres, senhores de seu território e de seus desejos, pois deixaram de receber ordens e suas vontades não foram mais condicionadas.

Porém, numa análise mais profunda, buscamos encontrar os possíveis elementos alegóricos presentes nas oposições: branco $X$ negro, dominador $X$ dominado, colonizador $X$ colonizado. Percebemos que essas oposições e, principalmente, o fracasso final do branco norte-americano, em prol do negro, não estavam na narrativa por acaso, sugerem um propósito. Particularmente, percebemos que tal construção seria, como se o intelectual Dicke estivesse teorizando seus ideais críticos, sociológicos, literários e, ao mesmo tempo, materializando-os na prática ficcional através de seus personagens. Ao desviar da prática das narrativas tradicionais, em que a visão do negro ficou cristalizada como negativa, Dicke coloca por terra, não só o colonizador como dominador, por ser dono do capital, mas, sobretudo, o cânone literário, destruindo o conceito cultural de unidade e pureza, e tudo que ele representa.

Nessa linha de pensamento, ao questionar sobre a "atitude do artista em um país em evidente inferioridade com relação à cultura ocidental, a cultura da metrópole", Silviano Santiago, em seu livro Uma literatura nos trópicos (2000, p. 16), sugere que escritores assinalem nas narrativas sua presença, configurando temas 


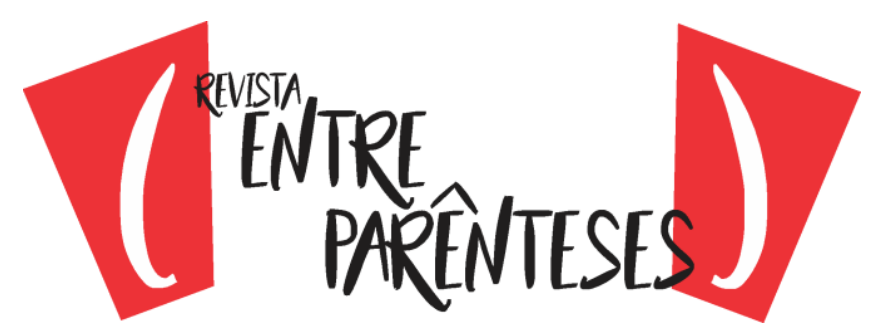

que marquem sua diferença. Conivente com tal pensamento, Dicke assinala sua presença, mostra a diferença - a identidade étnica brasileira nunca foi homogênea e, sim, hibrida, pois, no Brasil, conviveram, historicamente se misturando, o índio, o negro e o branco. Não adiantou a imposição dominadora hegemônica, porque, mais cedo ou mais tarde, o hibridismo aconteceu, ele existiu e ocorreu, naturalmente, como foi o caso da união do negro Pignon com a mulher branca norte-americana viúva de Mr. Filler em Caieira.

Nesse sentido, de um lado, os negros Pignon e Amância e, do outro lado, o norte-americano e sua esposa podem ser estereótipos, mas também máscaras criadas pelo escritor para "desmascarar" o velho e "revelar" o novo. A união do negro com a esposa do norte-americano, do ponto de vista superficial, pode significar apenas mais um caso em que uma branca se apaixona por um negro, porém, numa análise mais profunda, pode revelar certa complexidade. Alegoricamente, a união desses personagens, do ponto de vista sociológico, pode significar a aceitação de uma nova sociedade, a dos mestiços. Acontecimento que sugere uma reviravolta na noção de unidade e pureza representada na literatura brasileira com maior ênfase deste o pré-modernismo brasileiro.

E, do ponto de vista crítico-literário, a união de Pignon (negro e latinoamericano) com Sally (branca e norte-americana), num processo de mistura e "contaminação", sugere a descolonização das mentes - a aceitação do elemento híbrido, da miscigenação, da transculturação, como representações literárias. Procedimentos configurados em Caieira que, assim, como outros romances já escritos anteriormente por outros escritores nacionais, contribuem para a entrada da literatura da América Latina no mapa da civilização ocidental como representante legítimo da identidade nacional.

\section{REFERÊNCIAS}

ADORNO, Theodor. Teoria estética. São Paulo: Edições 70/Martins Fontes, 1970.

BERMAN, Marshall. Tudo que é sólido desmancha no ar. A aventura da modernidade. São Paulo: Companhia das Letras, 1986. 


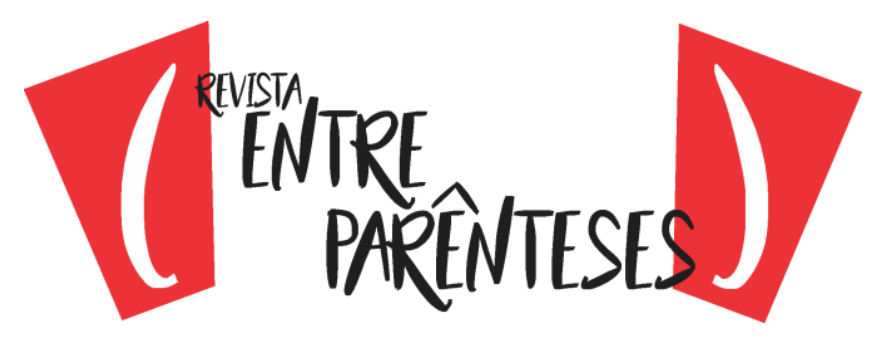

BHABHA, Homi K.. O local da cultura. Trad. Myrian Ávila, Eliana L.L. Reis e Gláucia R. Gonçalves. Belo Horizonte: UFMG, 1998.

BOÉTIE, Etienne De La. Discurso da servidão voluntária. Trad. Laymert Garcia dos Santos. Comentários: Claude Lefort. Pierre Clastres e Marilena Chauí. São Paulo: Brasiliense, 1982.

BONNICl, Thomas. Conceitos-chave da teoria pós-colonial. Maringá: Eduem, 2005.

BONNICl, Thomas. O Pós-colonialismo e a literatura: estratégias de leitura. Maringá: Eduem, 2000.

CANDIDO, Antônio. Educação pela noite. São Paulo: Ática, 1989.

CHAUÍ, Marilena. Intelectual engajado: uma figura em extinção? In: O silêncio dos intelectuais. Org. Adauto Novaes. São Paulo: Companhia das Letras, 2006.

DICKE, Ricardo Guilherme. Caieira. Rio de Janeiro: Francisco Alves, 1978.

LIMA, Luiz Costa. Dispersa demanda: ensaios sobre literatura e teoria. Rio de Janeiro: Livraria F. Alves, 1981.

LUKÁCS, Georg. A teoria do romance. Trad. José Marcos Mariani de Macedo. São Paulo: Duas Cidades, 2000.

PAZ, Octávio. Signos em rotação. Trad. Sebastião Uchoa Leite. São Paulo: Perspectiva, 1972.

PÉCAUT, Daniel. Os intelectuais e a política no Brasil. Trad. Maria Júlia Goldwasser. São Paulo: Ática, 1989.

ROBERT, Marthe. Romance das origens, origens do romance. Trad. André Telles. São Paulo: Cosac Naify, 2007.

SAID, Edward W.. Representações do intelectual. Trad. Milton Hatoum. São Paulo: Companhia das Letras, 2005.

SANTIAGO, Silviano. O entre-lugar do discurso latino-americano. In: Uma literatura nos trópicos: Rio de Janeiro: Rocco, 2000.

SANTIAGO, Silviano. As raízes e o Labirinto da América Latina. Rio de Janeiro: Rocco, 2006. 


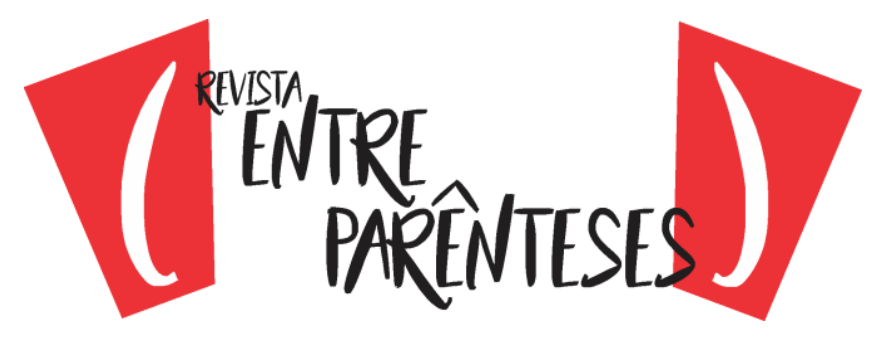

SARLO, Beatriz. Cenas da vida pós-moderna: intelectuais, arte e vídeo-cultura na argentina. Trad. Sérgio Alcides. Rio de Janeiro: Editora da UFRJ, 1997.

SARTRE, Jean-Paul. Em defesa dos intelectuais. Trad. Sérgio Góes de Paula. São Paulo: Ática, 1994.

Recebido em: 29/04/2018

Aceito em: 21/11/2018 